\title{
Research Methodology in Business: A Starter's Guide
}

\author{
Mohamed AF Ragab ${ }^{1, *} \&$ Amr Arisha ${ }^{1}$ \\ ${ }^{1}$ College of Business, Dublin Institute of Technology (DIT), Ireland \\ *Correspondence: College of Business, Dublin Institute of Technology (DIT), Aungier Street, Dublin, Ireland. E-mail: \\ mohamed.af.ragab@gmail.com, mohamed.ragab@dit.ie
}

Received: October 29, 2017 Accepted: November 28, $2017 \quad$ Online Published: December 13, 2017

doi:10.5430/mos.v5n1p1 URL: https://doi.org/10.5430/mos.v5n1p1

\begin{abstract}
A cardinal requisite of successful research lies in the proper selection of the research methodology applied to achieve research objectives using the available resources. In addition to acquiring sufficient knowledge of their specific research topic, researchers are urged to develop good understanding of alternative research methodologies at their disposal to be able to identify the best-suited methods to address the research question. This, however, often poses a challenge for novice researchers who face difficulty in grasping the vast methodology landscape and its encompassing array of debates. The purpose of this paper is to provide new researchers with a comprehensive overview of the main elements of research methodology, particularly in the business domain. After a brief introduction, the paper introduces the principles of research philosophy, approaches, and methods, and explains the different paradigmatic stances adopted by researchers in the field. A number of mixed methods designs are then discussed to highlight the different means by which qualitative and quantitative research are combined. The final section presents sampling techniques then explores the most prominent data-collection tools employed in business, including interviews, questionnaires, and case studies. The paper aims to offer business postgraduate students embarking on their research journeys with a useful summary that would guide in them navigating the methodological aspect of their research work.
\end{abstract}

Keywords: methodology; philosophy; pluralism; qualitative; quantitative; mixed methods

\section{Introduction}

Research could be defined as the "systematic investigation into and study of materials and sources in order to establish facts and reach new conclusions" (Oxford Dictionary, 2010). Research methodology determines how such investigation will take place and has been defined as "a way to systematically solve the research problem" (Kothari, 2004). Research of all types is predominantly based on certain underpinning assumptions about what constitutes valid research, and hence the use of appropriate methodology to achieve research objectives is vital to ensure credibility of the findings (Myers and Avison, 1997). There is no standard methodology that applies to all research cases, but rather the methodology has to be selected based on the nature and scope of the topic at hand and the type of data available (Bell, 2005). It is essential for research conducted with rigour to define its methodological choices and their underlying philosophical assumptions before engaging with data collection and analysis work (Brown and Sice, 2003). Thus, when planning their research projects, researchers should be cognisant of the strengths and weaknesses of different methodologies to make informed decisions on the selection of research methods, assess the appropriateness of such methods, be aware of their limitations, and justify their choices depending on the unique nature of the research endeavour (Easterby-Smith et al., 2002). This is by no means an easy task and poses a considerable challenge for young researchers. Commencing postgraduate students often face a "dilemma" in making methodological choices due to the numerous debates in the field (Knox, 2004; Mkansi and Acheampong, 2012). This paper attempts to offer a starting point for exploring research methodology in business through a succinct overview of its pertinent concepts. To portray a comprehensive picture of research methodology, its underlying components are outlined in the following sections. 


\section{Research Philosophy}

A typical starting point of the research process involves determining its philosophical stance using a research paradigm. In his seminal book, Kuhn (1962) defines a paradigm as "a set of linked assumptions about the world which is shared by the community of scientists and provides a conceptual framework for the organised study of the world." The research paradigm is imperative because it shapes the researcher's methodological approach used to investigate the research question. There are two fundamental schools of thought that influence current paradigms in scholarly research: the scientific and the humanistic, each providing opposing ontological and epistemological views (Amaratunga et al., 2002). Ontology is a branch of philosophy that studies the nature of reality and the essence of its existence (Burrell and Morgan, 1979). Once again, there are two main ontological perspectives: objective and subjective. Objectivism views reality as a "concrete structure" that exists "out there" external to humans and believes the world "predates individuals" and will continue to exist as a tangible entity regardless of people's actions (Holden and Lynch, 2004). This is the predominant view in the study of natural sciences. When applied to social sciences, an objective position assumes that social phenomena exist external to social actors (individuals). Subjectivism, on the other hand, maintains that reality is "created by individuals" and that the world is a mere "projection of the human mind" (Morgan and Smircich, 1980). While objectivists believe in a single reality, subjectivists believe that multiple realities could co-exist according to the different views of the world. In the subjectivist view, social phenomena are regarded as a contextual outcome of the actions and perceptions of social actors that are in a continual process of revision through the social interaction of such actors (Smircich, 1983).

Epistemology is the study of the nature of knowledge and how it is acquired and presents a similar two-fold debate between positivism and interpretivism -also referred to as phenomenology (Becker and Niehaves, 2007). Positivism adopts a scientific stance to research and aims to develop generalised findings from experimentation and structured observations of reality (Hussey and Hussey, 1997). When applied in the context of social science, the positivist paradigm assumes the researcher objectively obtains data while remaining external to the research process and independent of the subject of research, similar to the way a physical scientist would investigate physics or chemistry (Remenyi et al., 1998). The outcomes of positivist research are replicable factual generalisations about social phenomena.

Interpretivists argue that, unlike natural phenomena, social phenomena are unique because they are created by individuals in certain contexts and are too complex to be reduced to generalised rules and formulae (Crotty, 1998; Rowlands, 2005). Adopting a contrary stance to positivism, the phenomenological paradigm aims to study social phenomena from within their own context and considers that there is an interactive relationship between the researcher and the research subjects. Interpretive research stresses the role of human beings as social actors where a researcher obtains knowledge by entering the social world of research subjects to understand the phenomena being studied from their point of view in a subjective and empathetic manner (Holden and Lynch, 2004). The outcomes of interpretive research offer an understanding of the social phenomenon under investigation, and not the absolute truth, and therefore cannot be generalised to other contexts.

Crotty (1998) states that there is a confluence between ontology and epistemology making them difficult to separate from a conceptual perspective in the discussion of research methodology. He suggests they should be considered together because "to talk of the construction of meaning is to talk about the construction of meaningful reality." In other words, the view of reality (ontology) cannot be separated from the way of knowing about reality (epistemology). For example, an objectivist who believes in a single, tangible reality is likely to seek knowledge about the world in a scientific and positivist manner, and vice versa. Views of the two poles of the research paradigm spectrum are summarised in Table 1 below.

The debate between positivism and phenomenology leads purists on both sides to claim that a researcher has to take a stance on the bipolar debates on epistemology and ontology by adopting a single research philosophy (Guba and Lincoln, 1994). This view was based on the "incompatibility thesis" which posits that the positivist and phenomenological paradigms are fundamentally incompatible and could not be mixed or merged (Howe, 1988). The attempt to settle this conflict, however, led to the emergence of the pragmatic paradigm in the late $1800 \mathrm{~s}$.

Pragmatism is a research philosophy that focuses on the practical outcome of the research and rejects the "forced selection" between research paradigms (Tashakkori and Teddlie, 1998). The pragmatic paradigm is based on using "what works" and argues that it is possible to adopt more than one philosophy within the same research project to achieve research objectives. It allows researchers to apply whichever philosophical or methodological approach they find appropriate if it would have an effective contribution to addressing their research question. Tashakkori and Teddlie (1998) describe pragmatism as "study in the different ways in which you deem appropriate, and use the 
results in ways that can bring about positive consequences within your value system." They note that pragmatism is becoming a widespread research philosophy because it facilitates the usage of mixed method approaches and offers an alternative to what they refer to as "paradigm wars."

Table 1. Research Paradigms

\begin{tabular}{|c|c|c|}
\hline Paradigm & Scientific & Humanistic \\
\hline Ontology & Objectivism & Subjectivism \\
\hline Epistemology & Positivism & Interpretivism (Phenomenology) \\
\hline Views & $\begin{array}{l}\text { - The world is tangible and predates } \\
\text { individuals } \\
\text { - Singular reality } \\
\text { - The researcher is external to and } \\
\text { independent of the phenomena being } \\
\text { researched } \\
\text { - Research attempts to reduce phenomena } \\
\text { to context-free generalisations }\end{array}$ & $\begin{array}{l}\text { - The world is socially-constructed, } \\
\text { created by the minds of individuals } \\
\text { - Multiple realities } \\
\text { - The researcher is part of and interacts } \\
\text { with phenomena being researched } \\
\text { - Research attempts to provide a } \\
\text { contextually bounded understanding of } \\
\text { the phenomena }\end{array}$ \\
\hline
\end{tabular}

\section{Research Approach}

The development of a new theory could be addressed using two research approaches: deduction or induction (Figure 1). The first approach, deductive reasoning, begins by suggesting a theory and designs a research method to test this theory and so is also known as the "top-down approach" (Trochim and Donnelly, 2008). Deduction follows a highly structured methodology and often investigates casual relationships between variables to explain a certain phenomenon and generate generalisable findings The second approach, inductive theory-building, begins by specific observations in which patterns and relationships are identified to form a theory about a certain phenomenon and is referred to as the 'bottom-up' approach (Trochim and Donnelly, 2008). Induction is less concerned with generalisation, but rather with gaining a close understanding of the research phenomenon within its context and so adopts a more flexible structure to investigation (Easterby-Smith et al., 2002; Douglas, 2003).

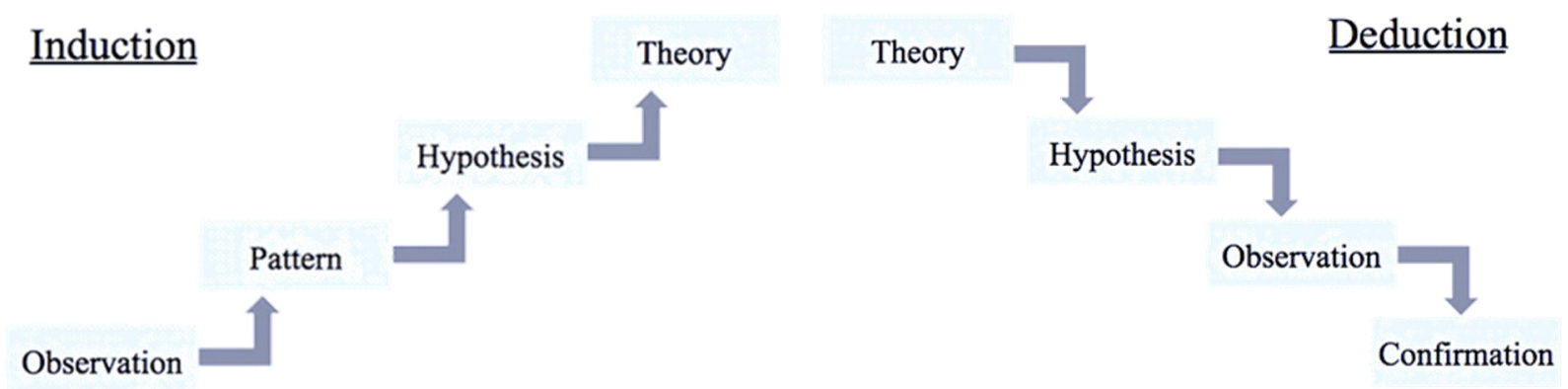

Figure 1. Induction and Deduction

When classifying research by its purpose, Saunders et al. (2009) propose a threefold classification of studies: exploratory, explanatory and descriptive. Exploratory research is defined as a means to discover "what is happening" and "to seek new insights" without investigating reasons (Robson, 2002). Explanatory research, on the other hand, seeks justifications and attempts to build causal relationships between variables of a certain phenomenon. Finally, descriptive studies aim only to "portray an accurate profile of persons, events or situations" (Robson, 2002). The two main research approaches and their corresponding characteristics are contrasted in Table 2. 
Table 2. Research Approaches

\begin{tabular}{|c|c|c|}
\hline Research Approach & Deduction & Induction \\
\hline Approach to investigation & Highly structured & Flexible \\
\hline Paradigm & Positivist & Interpretivist \\
\hline \multirow[t]{4}{*}{ Sequence of Investigation } & - $\quad$ Theory & - Observation \\
\hline & - Hypothesis & - Patterns \\
\hline & - Observation & - Hypothesis \\
\hline & - Confirmation & - Theory \\
\hline \multirow[t]{2}{*}{ Purpose } & Explanatory; & Exploratory; \\
\hline & $\begin{array}{l}\text { Explanation of causal relationships } \\
\text { between variables }\end{array}$ & $\begin{array}{l}\text { Gaining un understanding of the } \\
\text { phenomena }\end{array}$ \\
\hline Data Collected & Quantitative & Qualitative \\
\hline Generalisation & Need to generalise conclusions & Less concern with generalisation \\
\hline
\end{tabular}

\section{Research Methods}

Research Methods include the techniques that are used for conduction of research including data collection and analysis tools (Kothari, 2004). In distinguishing between research methods and methodology, the former can be envisaged as a subset of the latter. As Kothari states, "when we talk of research methodology we not only talk of the research methods but also consider the logic behind the method ... and explain why we are using a particular method and not others. "Research methods are generally categorised as having either a qualitative nature or a quantitative one, as explained below.3.2Statistics and Data Analysis

Analysis of data and the reporting of the results of those analyses are fundamental aspects of the conduct of research. Accurate, unbiased, complete, and insightful reporting of the analytic treatment of data (be it quantitative or qualitative) must be a component of all research reports. Researchers in the field of psychology use numerous approaches to the analysis of data, and no one approach is uniformly preferred as long as the method is appropriate to the research questions being asked and the nature of the data collected. The methods used must support their analytic burdens, including robustness to violations of the assumptions that underlie them, and they must provide clear, unequivocal insights into the data.

\subsection{Qualitative \& Quantitative Methods}

In light of the research philosophy, approach, and purpose, researchers have to decide on using quantitative and/or qualitative methods. Quantitative methods investigate phenomena through the collection of quantifiable data in numerical form and apply mathematical models and statistical techniques for data analysis (Creswell, 2002). In social science, quantitative research is often used to question relationships between variables yielding results that are predictive, explanatory, or confirmatory (Williams, 2011). It aims to produce generalised findings in the form of theories and formulae, and so is sometimes associated with positivistic and deductive studies (Bryman, 2012). Quantitative research methods include experiment, surveys, structured observations, and structured interviews. The main disadvantage of quantitative research designs is the inability to uncover underlying meanings of social phenomena, particularly when depth is required in studies of humanistic variables such as sociological and physiological factors (Amaratunga et al., 2002).

In contrast, qualitative research depends on words rather than numbers, and can be generally described as research the findings of which are not produced by means of quantification (Strauss and Corbin, 1990). It adopts a holistic view that seeks discovery from involvement in the actual experiences and aims to provide an in-depth understanding of social phenomena by exploring and interpreting collected data (Williams, 2011). Qualitative data includes narrative or descriptive accounts mostly in the form of text (Gulati, 2009). It is analysed using such methods as thematic analysis and content analysis to uncover patterns and themes that emerge from within the data (Taylor-Powell and Renner, 2003; Braun and Clarke, 2006). Since this genre of research is less structured and focuses on the development of meaning, it is often applied in interpretivist and inductive research (Guest et al., 2012). Qualitative research methods include case studies, grounded theory, ethnography, content analysis, and phenomenological studies. Although generalisations are not sought in this type of research, the inability to generalise 
the findings of qualitative study is considered a disadvantage because findings would be only relevant to a relatively small population who share the study's context (Johnson and Onwuegbuzie, 2004; Amaratunga et al., 2002). The main strengths and weaknesses of qualitative and quantitative methods are summarised in Table 3 below.

Table 3. Qualitative and Quantitative Methods: Strengths and Weaknesses

\begin{tabular}{|c|c|c|}
\hline & Quantitative Methods & Qualitative Methods \\
\hline & $\begin{array}{l}\text { - Testing and validating previously constructed } \\
\text { theories about how phenomena occur. } \\
\text { - Research findings could be generalised when data } \\
\text { is sufficient and based on a random sample. } \\
\text { - Can eliminate the confounding influence of many } \\
\text { variables, allowing one to assess cause-and-effect } \\
\text { relationships. } \\
\text { - Data collection and analysis is relatively less time } \\
\text { consuming and provides precise numerical data. } \\
\text { - Research results are relatively independent of the } \\
\text { researcher. } \\
\text { - Useful for large sample sizes. }\end{array}$ & $\begin{array}{l}\text { - Data is based on the participants' own } \\
\text { categories of meaning. } \\
\text { - Useful for studying a limited number of cases } \\
\text { in-depth and describing complex phenomena. } \\
\text { - Provides understanding and description of } \\
\text { people's personal experiences of phenomena } \\
\text { (i.e. insider's viewpoint). } \\
\text { - Can describe, in rich detail, phenomena as they } \\
\text { are situated and embedded in local contexts. } \\
\text { - Can determine how participants interpret } \\
\text { constructs } \\
\text { - Determine idiographic causation (i.e. causes of } \\
\text { events). }\end{array}$ \\
\hline 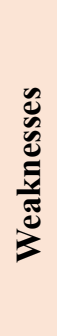 & $\begin{array}{l}\text { - Researcher's theories developed from the data may } \\
\text { not reflect local constituencies' understandings. } \\
\text { - May miss out on phenomena occurring because of } \\
\text { the focus on theory testing rather than on theory } \\
\text { generation. } \\
\text { - Knowledge produced may be too abstract and } \\
\text { general for direct application to specific contexts. }\end{array}$ & $\begin{array}{l}\text { - Findings produced may not be generalised to } \\
\text { other settings. } \\
\text { - More difficult to test hypotheses and theories. } \\
\text { - Data collection and analysis is often time } \\
\text { consuming. } \\
\text { - Results are influenced by the researcher's } \\
\text { personal biases. }\end{array}$ \\
\hline
\end{tabular}

Adapted from Johnson and Onwuegbuzie (2004)

Stemming from a pragmatist paradigm, the pluralistic and integrative view suggests that quantitative and qualitative methods should not be perceived as opposites but rather as complementary, which gave rise to mixed methods research. The key strength of mixed methods is that its combination of qualitative and quantitative methods offsets the weaknesses of both (Azorín and Cameron, 2010) and hence are often referred to as the "third methodological movement" (Cameron, 2011). For example, qualitative data could supplement quantitative studies with deeper meaning and insights, while quantitative methods may support qualitative inquiries in producing statistically representative findings. A number of other benefits of using mixed methods were identified by Green et al. (1989) based on their analysis of various research studies. These include:

- Triangulation - Convergence and corroboration of results from different methods to increase the validity of findings.

- Complementarity - Elaboration and clarification of results from one method with the results from the other to improve interpretability and meaningfulness.

- Development - Utilisation of the results from one method to help develop or inform the other method to enhance the validity of constructs.

- Initiation - Discovery of contradiction by comparing data from one method with data from the other to increase the strength of results and their interpretation by analysing them from the different perspectives.

- Expansion - Extension of the breadth and depth of research by using different methods for different stages of inquiry (Greene et al., 1989). 
Consequently, mixed methods have become increasingly popular in management research (Azorín and Cameron, 2010).

\subsection{Mixed Method Design}

In applying mixed methods, Creswell (2012) gives a valuable account of the different ways in which qualitative and quantitative methods can be combined in the research design to accomplish research aims. Alternative designs vary in the sequence of qualitative and quantitative phases and the sources of data for each of them. To this end, he proposes six designs depicted in Table 4 below.

Table 4. Mixed Methods Designs (Creswell, 2012)

\begin{tabular}{|c|c|c|}
\hline Design & Description & Purpose \\
\hline $\begin{array}{l}\text { Convergent Parallel } \\
\text { Mixed Methods }\end{array}$ & $\begin{array}{l}\text { Both quantitative and qualitative data are collected using the } \\
\text { same variables, analysed separately, and compared. }\end{array}$ & $\begin{array}{l}\text { Corroboration of } \\
\text { results }\end{array}$ \\
\hline $\begin{array}{l}\text { Explanatory } \\
\text { Sequential Mixed } \\
\text { Methods }\end{array}$ & $\begin{array}{l}\text { Quantitative data is collected and analysed in the first phase. } \\
\text { Qualitative data is collected in the second phase to help } \\
\text { explain the and interpret findings of the first. }\end{array}$ & $\begin{array}{l}\text { Deeper } \\
\text { understanding of } \\
\text { results }\end{array}$ \\
\hline $\begin{array}{l}\text { Exploratory } \\
\text { Sequential Mixed } \\
\text { Methods }\end{array}$ & $\begin{array}{l}\text { Qualitative data is collected and analysed in the first phase. } \\
\text { The outcomes are used to inform the design of the } \\
\text { quantitative data collection tool. } \\
\text { Quantitative data is collected in the second phase from a } \\
\text { large population to generalise the findings. }\end{array}$ & $\begin{array}{l}\text { Generalisation of } \\
\quad \text { findings }\end{array}$ \\
\hline $\begin{array}{l}\text { Embedded Mixed } \\
\text { Methods }\end{array}$ & $\begin{array}{l}\text { Nests several forms of data simultaneously (qualitative, } \\
\text { quantitative, or both) within a larger design }\end{array}$ & $\begin{array}{l}\text { Testing an } \\
\text { intervention in an } \\
\text { applied context }\end{array}$ \\
\hline $\begin{array}{l}\text { Transformative } \\
\text { Mixed Methods }\end{array}$ & $\begin{array}{l}\text { Incorporates elements of the convergent, explanatory } \\
\text { sequential, or exploratory sequential designs within a social } \\
\text { justice framework }\end{array}$ & $\begin{array}{l}\text { Studying } \\
\text { marginalised groups }\end{array}$ \\
\hline $\begin{array}{l}\text { Multiphase Mixed } \\
\text { Methods }\end{array}$ & $\begin{array}{l}\text { Conduction of several mixed methods studies in the same } \\
\text { project }\end{array}$ & $\begin{array}{l}\text { Long-term } \\
\text { evaluation projects }\end{array}$ \\
\hline
\end{tabular}

\section{Research Tool and Techniques}

\subsection{Sampling}

Sampling refers to the study of a small group of "cases" that represent the larger population (Henry, 1990). It is widely used in research because resource constraints often make it unfeasible for the researcher to collect data from the entire population i.e. conduct a census (Saunders et al., 2009). Sampling offers a practicable and effective alternative and allows for implementation of research projects within time and budget limits. It may even provide higher accuracy of results than a census because the limited number of cases within the sample allows for more time to be allocated to tasks such as the design and testing of the data collection instrument, collection of rich data, and in-depth analysis of the collected data (Henry, 1990).

The sampling design process is usually outlined in the following five steps: (1) Define the population, (2) Determine the sampling frame, (3) Select the sampling technique, (4) Determine the sample size, and (5) Execute the sampling process (Malhotra et al., 2004). A population represents the universe of units that share common attributes from which a sample is selected (Bryman, 2012). In the context of data collection, the population would encompass individuals who hold the information the researcher wishes to obtain in order to address the research question. Within the population, a sampling frame is a list of all individuals from which the sample could be selected (Greener, 2008). The main sampling techniques that fall under each of the two categories are described in Table 5 below. 
Table 5. Sampling Techniques (Saunders et al., 2009)

\begin{tabular}{|c|c|c|}
\hline & Techniques & Description \\
\hline \multirow{5}{*}{ 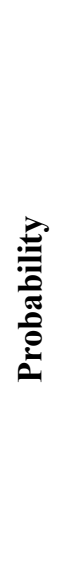 } & $\begin{array}{l}\text { Simple } \\
\text { Random }\end{array}$ & $\begin{array}{l}\text { Selecting the sample randomly from the sampling frame using random numbers } \\
\text { obtained from tables or generated by a computer. }\end{array}$ \\
\hline & Systematic & Selecting the sample at regular intervals from the sampling frame. \\
\hline & $\begin{array}{l}\text { Stratified } \\
\text { Random }\end{array}$ & $\begin{array}{l}\text { Dividing the population into a number of groups based on certain attributes, then } \\
\text { applying random sampling (simple or systematic) to each group. }\end{array}$ \\
\hline & Cluster & $\begin{array}{l}\text { Dividing the population into a number of groups (clusters) based on naturally } \\
\text { occurring attributes, then applying random sampling to select clusters. Data is } \\
\text { collected from every individual within selected clusters. }\end{array}$ \\
\hline & Multi-stage & $\begin{array}{l}\text { Uses a series of sampling frames by dividing the population into clusters then } \\
\text { levels of sub-clusters, and selecting sub-clusters using random sampling. }\end{array}$ \\
\hline \multirow{5}{*}{ 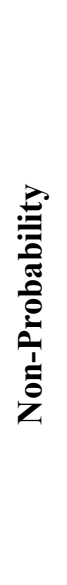 } & Quota & $\begin{array}{l}\text { Using stratified sampling and selecting individuals from each group using } \\
\text { predefined quotas for each group. Attempts to produce a sample that has the } \\
\text { same variability as that which occurs naturally in the population. }\end{array}$ \\
\hline & $\begin{array}{c}\text { Purposive } \\
\text { (Judgemental) }\end{array}$ & $\begin{array}{l}\text { Using judgement to select particularly informative individuals will enable the } \\
\text { researcher to meet research objectives. }\end{array}$ \\
\hline & Snowball & $\begin{array}{l}\text { Making contact with few individuals and asking them to nominate other } \\
\text { individuals until the desired sample size is reached. }\end{array}$ \\
\hline & Self-selection & Allowing individuals to express their desire to take part in the research process. \\
\hline & $\begin{array}{l}\text { Convenience } \\
\text { (Haphazard) }\end{array}$ & $\begin{array}{l}\text { Selecting individuals that are easiest to access at random until the desired sample } \\
\text { size is reached. }\end{array}$ \\
\hline
\end{tabular}

Sampling techniques can be categorised into two main types: probability sampling and non-probability sampling. Within probability sampling, each individual in the population has an equal chance (or probability) of being randomly selected in order to produce a sample that is statistically representative of the population. By contrast, in non-probability sampling techniques the selection of individuals from the population is not random and is determined by the researcher (Greener, 2008). While probability sampling is widely used in quantitative studies, qualitative studies tend to rely on the non-probability approach in the selection of sampling techniques (Anderson, 2009). Once the boundaries of the sample are determined, a data-collection instrument is employed within the sampling frame. The most widely techniques used are described below.

\subsection{Interviews}

An interview is "a purposeful discussion between two or more people" and a reliable method to gather research data (Kahn and Cannell, 1957). It originated as a research tool from psychology and psychiatry and is one of the most widely used methods in qualitative research (Bryman, 2006). Interviews are popular among both researchers and respondents because they permit face-to-face interaction and provide deep and holistic insights about research topics (Easterby-Smith et al., 2002).

They are classified by their level of formality starting from structured interviews to unstructured ones (Bryman, 2012). Structured interviews use a set of identical questions which are asked in a predetermined order to all respondents and may offer the interviewee a fixed range of answers. They are very similar to questionnaires and are 
used to collect mostly quantitative data from respondents. By contrast, unstructured interviews are similar to informal discussions and do not have standardised questions, but only a list of topics that are covered. The interviewers may alter the questions between interviews and allow respondents to express themselves freely in relation to the topic under study (Healey and Rawlinson, 1994). Semi-structured interviews fall between both ends of the spectrum as they have a predetermined set of questions, however, they allow a high degree of flexibility to ask new questions or discard existing ones, and allow new ideas to emerge during the discussion. Moreover, the sequence of questions may also vary depending on the flow of the conversation (Greener, 2008).

As a data collection method, interviews can be advantageous in terms of offering comprehensive in-depth information, new insights, and a high response rate due to the fact that they are mostly scheduled in advance (Bailey, 2008; Bell, 2005; Denscombe, 2003). They also enable the researcher to explore new issues that might arise, seek further explanation, and eliminate any misunderstandings in the concepts discussed with the interviewee (DiCicco Bloom and Crabtree, 2006). Nevertheless, there are some limitations to interviews that should be taken into consideration. For example; data collection, transcription, and analysis of interviews usually require a significant amount of time, especially if interviewees are based in different geographical locations (Bailey, 2008). Accordingly, the researcher can only conduct interviews with a small sample of respondents. In addition, interviews are prone to response bias in the sense that interviewees may perceive certain responses to be more desirable than their actual views, or can be influenced by the interviewer's opinion (Healey and Rawlinson, 1994).

Once interviews are transcribed, there are several qualitative techniques that are used to analyse the textual transcripts of interview data. They focus on identifying, analysing, and reporting patterns within the text (Braun and Clarke, 2006). (Riessman, 2005) proposes a four-fold typology for methods of analysing textual narratives depending on the main emphasis of the analysis (Table 6). She acknowledges, however, that there is a degree of overlap among these methods and that the boundaries between them are not clear-cut.

Table 6. Types of Narrative Analysis (Riessman, 2005)

\begin{tabular}{|c|c|}
\hline $\begin{array}{l}\text { Thematic } \\
\text { Analysis }\end{array}$ & $\begin{array}{l}\text { Emphasis is on the content of a text, "what" is said more than "how" it is } \\
\text { said. Identifies themes of meaning. }\end{array}$ \\
\hline $\begin{array}{l}\text { Discourse/ } \\
\text { Structural Analysis }\end{array}$ & $\begin{array}{l}\text { Emphasis shifts to the way a story is told. Focuses on language used, } \\
\text { frequency of the words, their relationships, and structures. }\end{array}$ \\
\hline $\begin{array}{c}\text { Interactional } \\
\text { Analysis }\end{array}$ & $\begin{array}{l}\text { Emphasis is on the dialogic process between teller and listener. Considers } \\
\text { pauses, interruptions, topic chaining and other aspects of conversation. }\end{array}$ \\
\hline $\begin{array}{l}\text { Performative } \\
\text { Analysis }\end{array}$ & $\begin{array}{l}\text { Envisages dialogue as a performance which addresses an audience } \\
\text { through language and gesture, "doing" rather than only "telling." }\end{array}$ \\
\hline
\end{tabular}

\subsection{Questioannires}

A questionnaire is a general title that includes methods in which each person is asked to respond to an identical set of questions in a predetermined order at a certain point in time (De Vaus, 2002; Bailey, 2008). It is the most widely used method for collection of primary data (Diamantopoulos and Schlegelmilch, 1996). It is popular in business research because it has the ability to harness data from a large sample, that may be geographically dispersed, and provides broad statistical analysis options (Zikmund, 2003). Moreover, because questionnaires are mostly completed at the convenience of respondents, they can be used to obtain a significant amount of information using a diversity of question types (Evans and Mathur, 2005; Bryman, 1992).

Purposes of using questionnaires can be either descriptive or explanatory (Gill and Johnson, 2010). While the former seeks to describe the characteristics of a population, the latter gathers data to test a hypothesis or theory. In distinguishing between them, Oppenheim (1992) defines descriptive questionnaires as simply aiming "to count" in order find out the proportions of the population that have a certain view or characteristic without studying causality or offering explanations. Explanatory questionnaires, on the other hand, involve a more analytical perspective where there is interest in investigating the relationship between variables. They therefore require predetermination of the variables that would be examined before the questionnaire is designed (Ghauri and Grønhaug, 2005). Such variables are usually identified in previous stages of the research and typically involve qualitative primary or secondary data. 
In utilising questionnaires, there are three types of variables that could be obtained: [1] Opinion variables which represent respondents' views (what they think), [2] Behaviour variables which convey respondents' actions (what they do), and [3] Attribute variables that record respondents' characteristics, (what they are) such as demographic data (Dillman, 2002). Awareness of the type of variable is important because it guides the selection of questions types, whether open-ended or closed-ended. Open-ended questions are similar to interview questions in that they allow respondents to reply freely in words (Fink, 2002). Because they are of a qualitative nature and require additional analysis, their use is not recommended in questionnaires (Saunders et al., 2009). Closed-ended questions, on the other hand, restrict the respondent to a number of answers to choose from (Foddy and Foddy, 1994) and include six main formats which are listed in Table 7 below.

Table 7. Questionnaire Closed-ended Question Formats

\begin{tabular}{|c|c|c|c|}
\hline Question Format & Description & Purpose & Example Variable \\
\hline List & $\begin{array}{l}\text { Respondents are offered a list of } \\
\text { items, any of which may be } \\
\text { selected }\end{array}$ & $\begin{array}{l}\text { To ensure respondents } \\
\text { have considered all } \\
\text { possible responses }\end{array}$ & Industry \\
\hline Category & $\begin{array}{l}\text { Only one response can be } \\
\text { selected from a given set of } \\
\text { mutually exclusive categories }\end{array}$ & $\begin{array}{l}\text { To collect behavioural or } \\
\text { attribute data }\end{array}$ & Annual income \\
\hline Ranking & $\begin{array}{l}\text { Respondents are asked to place } \\
\text { something in order }\end{array}$ & $\begin{array}{l}\text { To discover relative } \\
\text { importance }\end{array}$ & $\begin{array}{c}\text { Factors that affect a } \\
\text { certain decision }\end{array}$ \\
\hline Rating & $\begin{array}{l}\text { Respondents are given a rating } \\
\text { scale used to record responses }\end{array}$ & To collect opinion data & $\begin{array}{c}\text { Level of agreement } \\
\text { with a statement }\end{array}$ \\
\hline Quantity & $\begin{array}{l}\text { Respondents are asked to reply } \\
\text { with a number }\end{array}$ & $\begin{array}{l}\text { To obtain the numerical } \\
\text { amount of an attribute or } \\
\text { behaviour }\end{array}$ & Age \\
\hline Grid & $\begin{array}{l}\text { Responses to more than one } \\
\text { question are recorded using the } \\
\text { same matrix. }\end{array}$ & To save time & - \\
\hline
\end{tabular}

Validity and reliability are key aspects in the evaluation of questionnaire designs. Validity assesses whether or not a questionnaire is measuring what it intends to measure (Zikmund, 2003). It is evaluated by experts in the field whose feedback is commonly sought during questionnaire design. Similarly, reliability refers to repeatability i.e. the ability of the questionnaire to produce consistent findings whenever administered (Oppenheim, 1992). A common method to assess reliability of questionnaires is the Cronbach's Alpha statistic which uses inter-item correlations to measure internal consistency (Rattray and Jones, 2007). Even after confirming validity, it is strongly recommended that questionnaires are tested before being administered. This is achieved by running a pilot study using a copy of the actual questionnaire on a small sample of respondents that has the same characteristics as the intended sampling frame (De Vaus, 2002).

Questionnaires are also classified according to the way they are administered (Zikmund, 2003). Self-administered questionnaires are completed by respondents and could be sent electronically via the Internet, mailed by post, or delivered by hand to each respondent and collected at a later time. In the case of interviewer-administered questionnaires, data is recorded by the researcher based on respondents' answers obtained by telephone or in a face-to-face interview. The choice of the appropriate questionnaire method depends on a number of criteria including the research purpose, characteristics of the target population, and the financial and time resources available to the 
researcher (Fowler, 1995; Oppenheim, 1992). While self-administered questionnaires have the advantage of wide reach, particularly if distributed electronically, they risk yielding lower response rates if respondents perceive the questionnaires as impersonal or uninteresting and so opt not to answer its questions (Evans and Mathur, 2005). To overcome this challenge, studies proposed a number of measures to increase response rate. These include sending personalised cover letters, offering incentives, repeated contact with respondents, ensuring confidence in anonymity, and avoiding long questionnaires and difficult questions (Dillman et al., 1993; Diamantopoulos and Schlegelmilch, 1996; Meckel et al., 2005).

\subsection{Case Studies}

A case study is "an empirical inquiry that investigates a contemporary phenomenon within its real life context" and "relies on multiple sources of evidence" (Yin, 2014). Case studies are widely used in business research as they offer rich and reliable results due to the amalgamation of quantitative and qualitative data collection and analysis methods and the triangulation of information from multiple sources (Robson, 1993). They serve a number of research purposes such as providing descriptive accounts, theory development, and theory testing (Yin, 2011). In situations where the aim is theory development, case studies adopt an exploratory and inductive approach that requires limited prior theoretical knowledge and aims to generate theory from close observation of the phenomenon within its own context (Eisenhardt, 1989).However, when utilising case studies for theory testing purposes, propositions that are tested should be predetermined by the researcher to allow the comparison of actual outcomes of the case study with expected outcomes based on the proposed theory (Darke et al., 1998). In this case, studies are deductive and result in either the validation of the theory, its modification, or its refinement based on the case study results.

Case selection is a challenging yet crucial task in case study research. Random sampling, although unbiased, may produce cases that are unrepresentative of the population and hence non-probability purposeful sampling is often recommended to obtain a representative case (Seawright and Gerring, 2008). To this end, five methods of purposeful case selection could be identified and are described in Table 8 below.

Table 8. Methods for Case Selection

\begin{tabular}{|c|c|c|}
\hline Method & Description & Use \\
\hline Typical cases & Cases that are representative of the population & Confirmatory \\
\hline Extreme / Deviant cases & Unusual cases; particularly good or particularly problematic & Exploratory \\
\hline $\begin{array}{l}\text { Maximum variation } \\
\text { cases }\end{array}$ & $\begin{array}{l}\text { Using multiple heterogeneous cases to obtain data under varied } \\
\text { circumstances }\end{array}$ & Exploratory \\
\hline Critical cases & $\begin{array}{l}\text { Cases that permit logical deductions because they make a point } \\
\text { dramatically i.e. if it is true in this one case, then it is likely to be true } \\
\text { of all other cases }\end{array}$ & Confirmatory \\
\hline
\end{tabular}

Adapted from Flyvbjerg (2006) and Seawright and Gerring (2008)

Another important factor in case study research is determining the number of cases to be investigated. Løkke and Sørensen (2014) suggest that this number is correlated to the number of theories being examined. When the number of theories to be tested is small, multiple case studies would be undertaken to examine the validity of those theories in different contexts. However, if the number of tested theories increases, a single case study would be more credible because all theories are evaluated under the same unique conditions. This is because the investigation of multiple theories via multiple case studies may become unfeasible due to limitations in the capacity to analyse significantly large amounts of data, a threshold Lokke and Sorensen refer to as the "efficiency boundary" (Figure 2). 


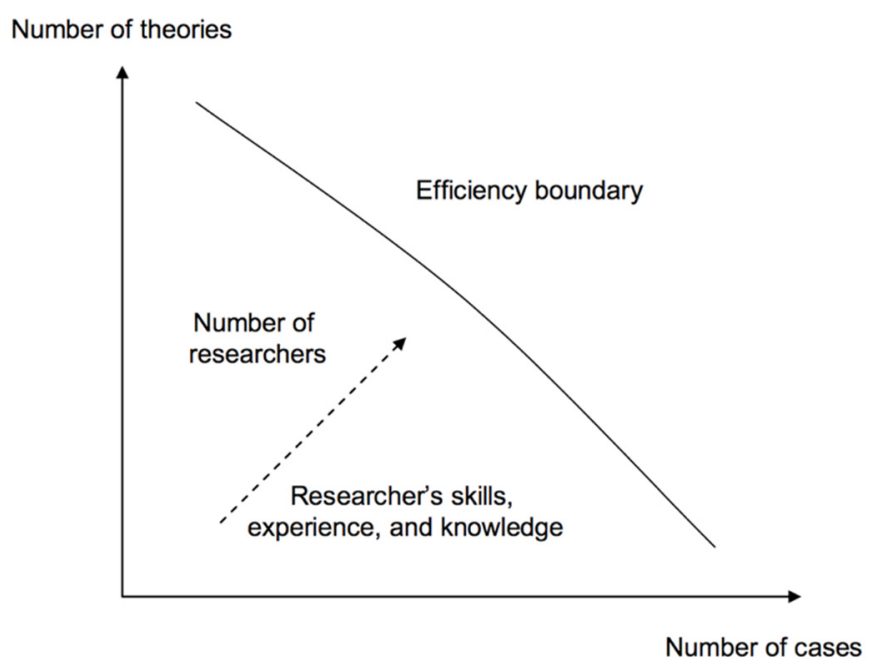

Figure 2. Number of Case Studies (Løkke and Sørensen, 2014)

\section{Conclusion}

In their study of perceptions of research methodology, Mkansi and Acheampong (2012) report that despite the abundance of textbooks and classifications $\mathrm{PhD}$ students continue to experience confusion and difficulty in comprehending methodology concepts due to the numerous debates and classifications. They call for the development of models that would relieve researchers from conceptual dilemmas and offer a framework to help them get a grasp of a challenging field. This recommendation is echoed by this paper which attempts to introduce methodology to research students in a perspicuous manner. It should be noted, however, that it is by no means exhaustive, but rather presents a broad overview of methodological choices. For in-depth knowledge of the concepts discussed, the reader is encouraged to consult the list of references at the end of the paper.

\section{Acknowledgements}

The authors would like to thank Ms. SafaaYounis for her valuable help in formatting the paper.

\section{References}

Amaratunga, D., Baldry, D., Sarshar, M., \& Newton, R. (2002). Quantitative and qualitative research in the built environment: application of "mixed" research approach. Work Study, 51(1), 17-31. https://doi.org/10.1108/00438020210415488

Anderson, V. (2009). Research methods in human resource management: Chartered Institute of Personnel and Development.

Azorín, J. M., \& Cameron, R. (2010). The application of mixed methods in organisational research: A literature review. Electronic journal of business research methods, 8(2), 95-105.

Bailey, K. (2008). Methods of social research: Simon and Schuster.

Becker, J., \& Niehaves, B. (2007). Epistemological perspectives on IS research: a framework for analysing and systematizing epistemological assumptions. Information Systems Journal, 17(2), 197-214. https://doi.org/10.1111/j.1365-2575.2007.00234.x

Bell, J. (2005). Doing your Research Project. Buckingham: Open University Press.

Braun, V., \& Clarke, V. (2006). Using thematic analysis in psychology. Qualitative research in psychology, 3(2), 77-101. https://doi.org/10.1191/1478088706qp063oa

Brown, J., \& Sice, P. (2003). Towards a Second Order Research Methodology. Electronic journal of business 
research methods, 3(1), 25-36.

Bryman, A. (1992). Quantitative and qualitative research: further reflections on their integration. Mixing methods: Qualitative and quantitative research, 57-78.

Bryman, A. (2006). Integrating quantitative and qualitative research: how is it done? Qualitative research, 6(1), 97-113. https://doi.org/10.1177/1468794106058877

Bryman, A. (2012). Social research methods (4th ed.). Oxford university press.

Burrell, G., \& Morgan, G. (1979). Sociological Paradigms and Organisational Analysis: Heinemann, London.

Cameron, R. (2011). Mixed Methods Research: The Five Ps Framework. Electronic journal of business research methods, 9(2).

Creswell, J. W. (2002). Educational research: Planning, conducting, and evaluating quantitative and qualitative research (4th ed.): Prentice Hall.

Creswell, J. W. (2012). Qualitative inquiry and research design: Choosing among five approaches (3rd ed.). Lincoln, NB: Sage Publications.

Crotty, M. (1998). The foundations of social research: Meaning and perspective in the research process: Sage.

Darke, P., Shanks, G., \& Broadbent, M. (1998). Successfully completing case study research: combining rigour, relevance and pragmatism. Information Systems Journal, 8(4), 273-289.

De Vaus, D. A. (2002). Surveys in social research (5th ed.): Psychology Press.

Denscombe, M. (2003). The good research guide: for small scale social projects: Buckingham: Open University Press.

Diamantopoulos, A., \& Schlegelmilch, B. B. (1996). Determinants of industrial mail survey response: A survey-on-surveys analysis of researchers' and managers' views. Journal of Marketing Management, 12(6), 505-531. https://doi.org/10.1080/0267257x.1996.9964432

DiCicco-Bloom, B., \& Crabtree, B. F. (2006). The qualitative research interview. Medical education, 40(4), $314-321$. https://doi.org/10.1111/j.1365-2929.2006.02418.x

Dillman, D. A., Sinclair, M. D., \& Clark, J. R. (1993). Effects of questionnaire length, respondent-friendly design, and a difficult question on response rates for occupant-addressed census mail surveys. Public Opinion Quarterly, 57(3), 289-304. https://doi.org/10.1086/269376

Douglas, D. (2003). Inductive theory generation: A grounded approach to business inquiry. Electronic journal of business research methods, 2(1), 47-54.

Easterby-Smith, M., R., T., \& Lowe, A. (2002). Management research: an introduction (2nd ed.). Sage.

Eisenhardt, K. M. (1989). Building theories from case study research. Academy of management review, 14(4), 532-550. https://doi.org/10.5465/amr.1989.4308385

Evans, J. R., \& Mathur, A. (2005). The value of online surveys. Internet research, 15(2), $195-219$. https://doi.org/10.1108/10662240510590360

Fink, A. (2002). How to ask survey questions (Vol. 4): Sage.

Flyvbjerg, B. (2006). Five misunderstandings about case-study research. Qualitative inquiry, 12(2), $219-245$. https://doi.org/10.1177/1077800405284363

Foddy, W., \& Foddy, W. H. (1994). Constructing questions for interviews and questionnaires: theory and practice in social research. Cambridge university press. https://doi.org/10.1017/cbo9780511518201

Fowler, F. J. (1995). Improving survey questions: Design and evaluation (Vol. 38): Sage.

Ghauri, P. N., \& Grønhaug, K. (2005). Research methods in business studies: A practical guide. Pearson Education.

Gill, J., \& Johnson, P. (2010). Research methods for managers. Sage.

Greene, J. C., Caracelli, V. J., \& Graham, W. F. (1989). Toward a conceptual framework for mixed-method evaluation designs. Educational evaluation and policy analysis, 11(3), 255-274. https://doi.org/10.3102/01623737011003255

Greener, S. (2008). Business research methods. Frederiksberg: Ventus Publishing. 
Guba, E. G., \& Lincoln, Y. S. (1994). Competing paradigms in qualitative research. Handbook of qualitative research, 2, 163-194.

Guest, G., Namey, E. E., \& Mitchell, M. L. (2012). Collecting qualitative data: A field manual for applied research. Sage.

Gulati, P. (2009). Research Management: Fundamental \& Applied Research. Global India Publications Pvt.

Healey, M., \& Rawlinson, M. (1994). Interviewing techniques in business and management research. Dartmouth Publishing.

Henry, G. T. (1990). Practical sampling (Vol. 21): Sage.

Holden, M. T., \& Lynch, P. (2004). Choosing the appropriate methodology: understanding research philosophy. The marketing review, 4(4), 397-409. https://doi.org/10.1362/1469347042772428

Howe, K. R. (1988). Against the quantitative-qualitative incompatibility thesis or dogmas die hard. Educational researcher, 17(8), 10-16. https://doi.org/10.3102/0013189x017008010

Hussey, J., \& Hussey, R. (1997). Business Research: A Practical Guide for Undergraduate and Postgraduate Students. Basingstoke: Macmillan Press Ltd.

Johnson, R. B., \& Onwuegbuzie, A. J. (2004). Mixed methods research: A research paradigm whose time has come. Educational researcher, 33(7), 14-26. https://doi.org/10.3102/0013189x033007014

Kahn, R. L., \& Cannell, C. F. (1957). The dynamics of interviewing; theory, technique, and cases. Industrial \& Labor Relations Review, 12(4), 54-55

Knox, K. (2004). A researcher's dilemma-philosphical and methodological pluralism. The Electronic Journal of Business Research Methods, 2(2), 119-128.

Kothari, C. R. (2004). Research methodology: Methods and techniques. New Age International.

Kuhn, T. S. (1962). The structure of scientific revolutions. University of Chicago press.

Løkke, A.-K., \& Sørensen, P. D. (2014). Theory Testing Using Case Studies. Electronic journal of business research methods, 12(1).

Malhotra, N. K., Hall, J., Shaw, M., \& Oppenheim, P. (2004). Essentials of marketing research: an applied orientation. Pearson Education Australia.

Meckel, M., Walters, D., \& Baugh, P. (2005). Mixed-mode surveys using mail and web questionnaires. The Electronic Journal of Business Research Methodology, 3(1), 69-80.

Mkansi, M., \& Acheampong, E. A. (2012). Research philosophy debates and classifications: students' dilemma. Electronic journal of business research methods, 10(2), 132-140.

Morgan, G., \& Smircich, L. (1980). The case for qualitative research. Academy of management review, 5(4), 491-500.

Myers, M. D., \& Avison, D. (1997). Qualitative research in information systems. Management Information Systems Quarterly, 21, 241-242.

Oppenheim, A. N. (1992). Questionnaire design, interviewing and attitude measurement: Bloomsbury Publishing.

Oxford Dictionary. (Ed.) (2010) (3rd ed.). Oxford University Press.

Rattray, J., \& Jones, M. C. (2007). Essential elements of questionnaire design and development. Journal of clinical nursing, 16(2), 234-243. https://doi.org/10.1111/j.1365-2702.2006.01573.x

Remenyi, D., Williams, B., Money, A., \& Swartz, E. (1998). Doing Research in Business and Management - An Introduction to Process and Method. London: Sage Publications.

Riessman, C. K. (2005). Narrative analysis: University of Huddersfield.

Robson, C. (1993). Real world research: A resource for social scientists and practitioners-researchers. Massachusetts: Blackwell Pushers.

Robson, C. (2002). Real world research: A resource for social scientists and practitioner-researchers (Vol. 2): Blackwell Oxford.

Rowlands, B. H. (2005). Grounded in practice: Using interpretive research to build theory. The Electronic Journal of 
Business Research Methodology, 3(1), 81-92.

Saunders, M., Lewis, P., \& Thornhill, A. (2009). Research methods for business students: Prentice Hall.

Seawright, J., \& Gerring, J. (2008). Case Selection Techniques in Case Study Research A Menu of Qualitative and Quantitative Options. Political Research Quarterly, 61(2), 294-308. https://doi.org/10.4135/9781473915480.n31

Smircich, L. (1983). Concepts of culture and organizational analysis. Administrative science quarterly, 339-358.

Strauss, A., \& Corbin, J. M. (1990). Basics of qualitative research: Grounded theory procedures and techniques: Sage Publications.

Tashakkori, A., \& Teddlie, C. (1998). Mixed methodology: Combining qualitative and quantitative approaches (Vol. 46): SAGE Publications.

Taylor-Powell, E., \& Renner, M. (2003). Analyzing qualitative data: University of Wisconsin--Extension, Cooperative Extension.

Trochim, W. M., \& Donnelly, J. P. (2008). Research methods knowledge base (3rd ed.). Mason, OH: Atomic Dog/Cengage Learning.

Williams, C. (2011). Research methods. Journal of Business \& Economics Research (JBER), 5(3). https://doi.org/10.19030/jber.v5i3.2532

Yin, R. K. (2011). Applications of case study research. Sage Publications.

Yin, R. K. (2014). Case study research: Design and methods. Sage Publications.

Zikmund, W. G. (2003). Business Research Methods. Mason, Ohio: Thomson/South-Western. 